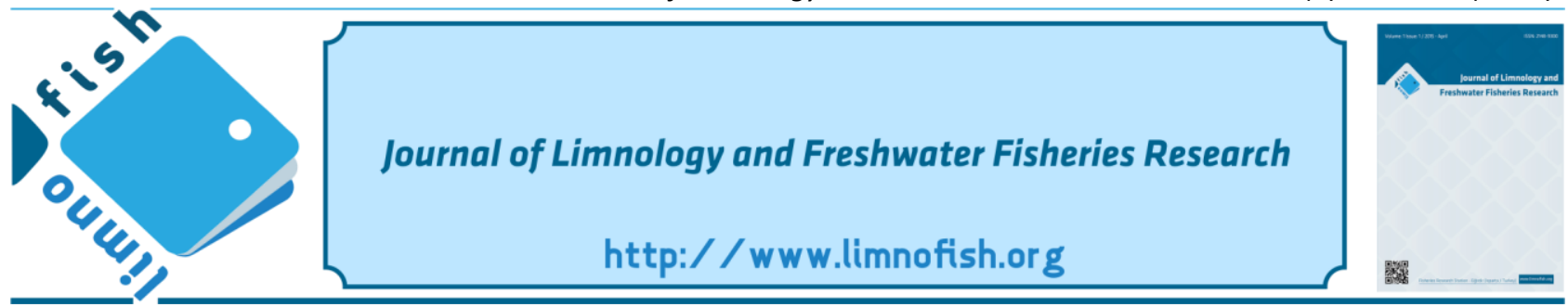

\title{
Global Length-Length Relationships for Common Carp Cyprinus carpio (Cypriniformes: Cyprinidae)
}

\author{
Lorenzo VILIZZI 1* (iD), Ali Serhan TARKAN 1,2 iD \\ ${ }^{1}$ Department of Ecology and Vertebrate Zoology, Faculty of Biology and Environmental Protection, University of Lodz, Lodz, \\ Poland \\ ${ }^{2}$ Department of Basic Sciences, Faculty of Fisheries, Muğla, Turkey
}

\section{A B STRACT}

A review is provided of length-length relationships (LLR) for common carp (Cyprinus carpio L., 1758) at the global scale. In total, 16 studies were retrieved from a comprehensive literature search that provided LLR for $C$. carpio populations from 26 water bodies consisting of rivers, lakes and reservoirs across nine countries in four continents. There was large variation in LLR, which were available for all six possible combinations of total, fork and standard length, due to the wide range of fish sizes measured. This is the first study that provides LLR for $C$. carpio that can be used as a reference base for future age-growth and population dynamics studies on this species.

Keywords: Size, growth, population dynamics, invasive species, Turkey
ARTICLE INFO

\section{REVIEW}

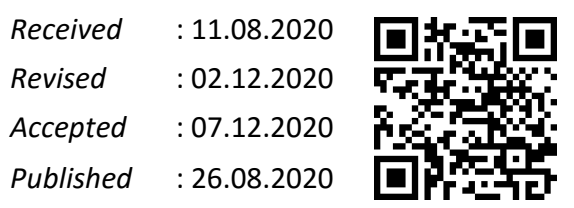

DOI:10.17216/LimnoFish. 778963

* CORRESPONDING AUTHOR

serhantarkan@gmail.com

Phone : +90252 2111888

\section{Sazan Cyprinus carpio (Cypriniformes: Cyprinidae) için Global Boy-Boy İlişkileri \\ Öz: Bu çalışmada küresel ölçekte sazanın Cyprinus carpio boy-boy ilişkilerinin bir derlemesi gerçekleştirilmiştir. Toplamda 16 çalışmada, dört kıtadan dokuz ülkedeki rezervuarlar, göller ve akarsuları içeren 26 su kütlesinden C. carpio popülasyonlarının boy-boy ilişkileri kapsamlı bir literatür taraması ile toplanmıştır. Çok geniş boy aralıklarının varlığı nedeniyle mümkün olan altı olası total, çatal ve standart boy kombinasyonları için boy-boy ilişkilerinde önemli varyasyonlar tespit edilmiştir. Bu çalışma, tür için gelecekte gerçekleştirilecek popülasyon dinamiği ve yaş-büyüme çalışmalarında referans olarak kullanılabilecek boy-boy ilişkilerini sağlayan ilk çalışmadır.}

Anahtar kelimeler: Boy, büyüme, popülasyon dinamikleri, istilacı tür, Türkiye

How to Cite

Vilizzi L, Tarkan AS, 2021. Global Length-Length Relationships for Common Carp Cyprinus carpio (Cypriniformes: Cyprinidae) LimnoFish. 7(2): 171-175. doi: 10.17216/LimnoFish.778963

\section{Introduction}

Length-length relationships (LLR) are important in fish stock and population assessment (Ricker 1968) and for comparative population growth studies (Binohlan et al. 1998). The common carp Cyprinus carpio is one of the most widely distributed freshwater fishes in the world (Froese and Pauly 2019), and is a species of particular ecological relevance due to its dual status of both vulnerable in its native area of distribution (Freyhof and Kottelat 2008) and noxious in most of its non-native areas (Vilizzi 2012; Vilizzi et al. 2015a). A plethora of agegrowth studies worldwide have provided length-atage, weight-length relationships and condition factors for this species, and these were recently reviewed in Vilizzi and Copp (2017). This study provides LLR for $C$. carpio based on a similar, comprehensive literature review. Such information is timely, because there are currently no peer-reviewed based LLR for this species available from FishBase (Froese and Pauly 2019) that can be used as a reference base for age-growth and population dynamics studies on C. carpio.

Length-length relationships for $C$. carpio were retrieved from publications in the peer-reviewed and 'grey' literature (cf. conference proceedings). For each study providing LLR, the following were recorded: (i) number of fish; (ii) minimum and 
maximum length type (if provided) used for the conversion [i.e. independent $\mathrm{Y}$ variable in the length-length equation $\mathrm{Y}=a+b \mathrm{X}$, where $\mathrm{X}$ is the dependent variable, and $\mathrm{Y}$ and $\mathrm{X}$ are either total length (TL), fork length (FL) or standard length (SL)]; (iii) parameters $a$ and $b$ of the length-length equation; (iv) coefficient of determination $r^{2}$; (v) water body and country of study; (vi) literature source. Whenever LLR were (also) provided for males and females separately, these were added to the database for completeness together with the LLR for the sexes combined.
In total, 16 studies were retrieved that provided LLR for $C$. carpio populations from 26 water bodies consisting of rivers, lakes and reservoirs across nine countries in Europe, Africa, Asia and Australasia (Table 1). Length-length relationships were available for all six possible combinations (i.e. as dependent/independent variables) of SL, FL and TL, with fish sizes ranging from $87 \mathrm{~mm}$ SL to $780 \mathrm{~mm}$ TL (Table 1). Overall, length-length equations, as described by parameters $a$ and $b$, were quite different across studies and this was mainly related to the large variation in the range of fish sizes used for the LLR computations.

Table 1. Length-length relationships for common carp Cyprinus carpio worldwide grouped according to type of conversion (i.e. $\mathrm{X} \rightarrow \mathrm{Y}$, where $\mathrm{X}$ is the predictor length type and $\mathrm{Y}$ is the response length type in the equation: $\mathrm{Y}=a+$ $b \mathrm{X}) . \mathrm{TL}=$ total length; $\mathrm{FL}=$ fork length; $\mathrm{SL}=$ standard length. For each water body, the following are provided: number of fish measured $(n)$, minimum $(\min )$ and maximum (max) predictor length type (if provided), parameters $a$ and $b$, coefficient of determination $r^{2}$, country, and source study. Decimal places are reported in all cases as per the original source.

\begin{tabular}{|c|c|c|c|c|c|c|c|c|}
\hline $\mathbf{n}$ & Min (mm) & $\operatorname{Max}(\mathbf{m m})$ & $\mathbf{a}$ & $\mathbf{b}$ & $\mathbf{r}^{2}$ & Water body & Country & Source \\
\hline \multicolumn{9}{|c|}{$\mathrm{TL} \rightarrow \mathrm{FL}(\mathrm{FL}=a+b \mathrm{TL})$} \\
\hline 601 & 111 & 767 & -12.167 & 0.929 & 0.999 & Lower River Murray & Australia & $(15)$ \\
\hline 35 & 207 & 598 & 0.661 & 0.8717 & 0.94 & Anzali Wetland & Iran & (10) \\
\hline 77 & 115 & 780 & -3.5872 & 0.9184 & - & Hirfanl1 Reservoir & Turkey & $(8)$ \\
\hline 114 & 199 & 300 & -6.622 & 1.020 & 0.978 & K'sob Reservoir & Algeria & $(9) \dagger$ \\
\hline 36 & 203 & 380 & -7.676 & 1.026 & 0.992 & K'sob Reservoir & Algeria & $(9) \ddagger$ \\
\hline 19 & 106 & 320 & 0.065 & 0.887 & 0.998 & Büyükçekmece Reservoir & Turkey & (12) \\
\hline 26 & 122 & 424 & -0.598 & 0.9024 & - & River Kızılırmak Basin & Turkey & (13) \\
\hline 20 & 140 & 180 & -18.02 & 1.045 & 0.995 & River Ganga & India & $(7) \S$ \\
\hline \multicolumn{9}{|c|}{$\mathrm{TL} \rightarrow \mathrm{SL}(\mathrm{SL}=a+b \mathrm{TL})$} \\
\hline 122 & 175 & 720 & 8.274 & 0.845 & - & Lake Vransko & Croatia & (14) \\
\hline 148 & - & - & -0.123 & 0.828 & 0.996 & Hirfanlı Reservoir & Turkey & (17) \\
\hline 83 & - & - & -0.104 & 0.829 & 0.995 & Hirfanl1 Reservoir & Turkey & $(17) \dagger$ \\
\hline 65 & - & - & -0.109 & 0.825 & 0.997 & Hirfanlı Reservoir & Turkey & $(17) \ddagger$ \\
\hline 114 & 199 & 300 & -9.626 & 1.012 & 0.986 & K'sob Reservoir & Algeria & $(9) \dagger$ \\
\hline 36 & 203 & 380 & -3.768 & 0.970 & 0.990 & K'sob Reservoir & Algeria & $(9) \ddagger$ \\
\hline 19 & 106 & 320 & 0.404 & 0.794 & 0.996 & Büyükçekmece Reservoir & Turkey & (12) \\
\hline 26 & 122 & 424 & -0.5260 & 0.817 & - & River Kızılırmak Basin & Turkey & (13) \\
\hline 20 & 140 & 180 & -40.12 & 1.115 & 0.982 & River Ganga & India & $(7) \S$ \\
\hline \multicolumn{9}{|c|}{$\mathrm{FL} \rightarrow \mathrm{SL}(\mathrm{SL}=a+b \mathrm{FL})$} \\
\hline 160 & 100.1 & 438.2 & -2.1977 & 0.8815 & - & River Guadalquivir & Spain & $(5) \Phi$ \\
\hline 26 & - & - & -0.1474 & 0.8991 & - & River Kızılırmak Basin & Turkey & (13) \\
\hline \multicolumn{9}{|c|}{$\mathrm{FL} \rightarrow \mathrm{TL}(\mathrm{TL}=a+b \mathrm{FL})$} \\
\hline 160 & 100.1 & 438.2 & -2.8817 & 1.1058 & - & River Guadalquivir & Spain & (5) \\
\hline 337 & 174.3 & 401.1 & 0.1584 & 1.0947 & 0.995 & Gelingüllü Reservoir & Turkey & (4) \\
\hline 142 & - & - & 1.10 & 1.07 & 0.99 & Altınkaya Reservoir & Turkey & (16) \\
\hline 65 & - & - & 0.80 & 1.08 & 0.99 & Altınkaya Reservoir & Turkey & $(16) \dagger$ \\
\hline 77 & - & - & 1.26 & 1.07 & 0.99 & Altınkaya Reservoir & Turkey & $(16) \ddagger$ \\
\hline 155 & - & - & -0.02 & 1.09 & 0.99 & Lakes Bafra Balık & Turkey & $(16)$ \\
\hline 74 & - & - & 0.13 & 1.08 & 0.99 & Lakes Bafra Balık & Turkey & $(16) \dagger$ \\
\hline 81 & - & - & -0.16 & 1.09 & 0.99 & Lakes Bafra Balık & Turkey & $(16) \div$ \\
\hline 97 & - & - & 2.13 & 1.04 & 0.99 & Derbent Reservoir & Turkey & (16) \\
\hline
\end{tabular}


(Table 1. continued)

\begin{tabular}{|c|c|c|c|c|c|c|c|c|}
\hline $\mathbf{n}$ & $\operatorname{Min}(\mathbf{m m})$ & $\operatorname{Max}(\mathbf{m m})$ & $\mathbf{a}$ & $\mathbf{b}$ & $\mathbf{r}^{2}$ & Water body & Country & Source \\
\hline 49 & - & - & 1.93 & 1.05 & 0.99 & Derbent Reservoir & Turkey & $(16) \dagger$ \\
\hline 48 & - & - & 2.02 & 1.04 & 0.99 & Derbent Reservoir & Turkey & $(16) \dagger$ \\
\hline 36 & - & - & 0.33 & 1.12 & 0.99 & Lake Karaboğaz & Turkey & (16) \\
\hline 6 & - & - & 0.39 & 1.11 & 0.99 & Lake Karaboğaz & Turkey & $(16) \dagger$ \\
\hline 30 & - & - & -0.23 & 1.08 & 0.99 & Lake Karaboğaz & Turkey & $(16) \downarrow$ \\
\hline 148 & 113 & 454 & 0.246 & 1.10 & 0.998 & Hirfanlı Reservoir & Turkey & (17) \\
\hline 83 & 133 & 454 & 0.209 & 1.10 & 0.997 & Hirfanlı Reservoir & Turkey & $(17) \dagger$ \\
\hline 65 & 113 & 425 & 0.274 & 1.10 & 0.998 & Hirfanlı Reservoir & Turkey & $(17) \ddagger$ \\
\hline 42 & 119 & 217 & -4.073 & 1.1815 & - & Lake Ula & Turkey & $(11)$ \\
\hline 120 & - & - & 0.1025 & 0.9612 & 0.998 & Dahmouni Reservoir & Algeria & (2) \\
\hline 38 & - & - & 0.0915 & 0.969 & 0.9984 & Dahmouni Reservoir & Algeria & $(2) \dagger$ \\
\hline 50 & - & - & 0.0974 & 0.9462 & 0.9979 & Dahmouni Reservoir & Algeria & (2) $\vdots$ \\
\hline \multicolumn{9}{|c|}{$\mathrm{SL} \rightarrow \mathrm{FL}(\mathrm{FL}=a+b \mathrm{SL})$} \\
\hline 602 & 87 & 647 & 8.667 & 1.097 & 0.995 & Lower River Murray & Australia & (15) \\
\hline 148 & - & - & 0.025 & 1.09 & 0.997 & Hirfanlı Reservoir & Turkey & (17) \\
\hline 83 & - & - & 0.058 & 1.09 & 0.996 & Hirfanlı Reservoir & Turkey & (17) \\
\hline 65 & - & - & -0.042 & 1.10 & 0.998 & Hirfanlı Reservoir & Turkey & (17) \\
\hline 42 & 104 & 187 & 5.8308 & 1.0695 & - & Lake Ula & Turkey & (11) \\
\hline \multicolumn{9}{|c|}{$\mathrm{SL} \rightarrow \mathrm{TL}(\mathrm{TL}=a+b \mathrm{SL})$} \\
\hline 12 & 117 & 409 & 0.2635 & 1.1937 & 0.999 & Lake İznik & Turkey & (6) \\
\hline 49 & 104 & 740 & 1.9500 & 1.1233 & 0.997 & Ömerli Dam & Turkey & (6) \\
\hline 42 & 93 & 172 & 2.7014 & 1.2645 & - & Lake Ula & Turkey & (11) \\
\hline 10 & 222.0 & 253.0 & 60.6 & 0.93 & 0.53 & Baghdad & Iraq & $(1) \S$ \\
\hline 10 & 213.0 & 259.0 & 118.3 & 0.68 & 0.58 & Babil & Iraq & $(1) \S$ \\
\hline 10 & 221.2 & 248.6 & 249.1 & 0.10 & 0.02 & Karbala & Iraq & $(1) \S$ \\
\hline 10 & 224.0 & 259.0 & 121.9 & 0.64 & 0.49 & Al-Najaf & Iraq & $(1) \S$ \\
\hline 10 & 239.0 & 295.0 & 195.9 & 0.47 & 0.32 & Dhi Qar & Iraq & $(1) \S$ \\
\hline 12 & 238.6 & 295.3 & 208.3 & 0.42 & 0.31 & Al-Muthanna & Iraq & $(1) \S$ \\
\hline 12 & 209.0 & 256.0 & 194.8 & 0.47 & 0.97 & Al-Basrah & Iraq & $(1) \S$ \\
\hline 100 & - & - & 0.30 & 1.18 & 0.99 & Three Gorges Reservoir & China & (3) \\
\hline
\end{tabular}

Source: (1) Al-jebory et al. (2018); (2) Askri et al. (2013); (3) Xie et al. (2019); (4) Ekmekçi (1996); (5) FernándezDelgado (1990); (6) Gaygusuz et al. (2006); (7) Kamboj and Kamboj (2019); (8) Kırankaya et al. (2014); (9) Mimeche et al. (2015); (10) Moradinasab et al. (2012); (11) Önsoy et al. (2011); (12) Saç and Okgerman (2016); (13) Sungur Birecikligil et al. (2016); (14) Treer et al. (1995); (15) Vilizzi (1997); (16) Y1lmaz et al. (2010a); (17) Y1lmaz, et al. (2010b).

$\dagger$ Parameter $a$ multiplied by 10 (original measurements in $\mathrm{cm}$ ). $\ddagger$ Males. $\S$ Females. SL measured at the hypural plate.

\section{Discussion}

This is the first study to provide a summary of LLR for $C$. carpio at the global scale, and together with the review by Vilizzi and Copp (2017) provides a comprehensive reference base for the "vital statistics' (sensu Ricker and Foerster 1948) regarding the age and growth of this species. Based on a comparative evaluation of TL, FL and SL for three cyprinid fishes including $C$. carpio, TL was suggested to be the most reliable length measurement (Önsoy et al. 2011). At the same time, the proportion of age-growth studies for $C$. carpio using FL was found to be larger than those relying on SL and TL
(Vilizzi and Copp 2017), with a strong bias towards the use of FL in studies from Anatolia (Vilizzi et al. 2015b) and the use of SL [cf. longitudo corporis (Balon 1957) or 'length to the base of $C^{\prime}$ (Berg 1964)] in studies from the former USSR. The LLR provided in the present study for all length type combinations as well as for a range of waterbody types (for which overall growth differences have been described by Vilizzi and Copp 2017), will help in the selection of the parameters 'best' suited to the $C$. carpio population(s) under 
investigation, including studies on both young-ofyear and adult fish.

\section{References}

Al-jebory TA, Das SK, Usup G, Bakar Y, Al-Saadi AH. 2018. Length-weight and length-length relationships of common carp (Cyprinus carpio L.) in the middle and southern Iraq provinces. In: AIP Conference Proceedings; AIP Publishing LLC, Vol. 1940, No. 1, p.020025.

doi:10.1063/1.5027940

Askri B, Daho O, Bensahla Talet L, Bensalah Talet A. 2013. Relations biométriques chez la carpe commune Cyprinus caprio [sic] (Linnaeus, 1758) pêchée dans le barrage Dahmouni (W. Tiaret). Paper presented at: 3eme Colloque International sur la Biodiversité et Ecosystèmes Littoraux; Oran, Algérie.

Balon EK. 1957. Vek a rast neresového stáda dunajského kapra-sazana (Cyprinus carpio morpha hungaricus Heck.) z Malého Dunaja nad Kolárovom [Age and growth of spawning school of the Danubian wild carp]. Pol'nohospodártsvo (Bratislava) 4:961-986. [In Slovak with an abstract in English].

Berg LS. 1964. Freshwater fishes of the U.S.S.R. and adjacent countries, Vol. 2. Jerusalem, Israel: Israel Program for Scientific Translations. 496 p.

Binohlan C, Froese R, Pauly D. 1998. The length-length table. In: Froese R, Pauly D, editors. Fishbase 1998: concepts, design and data sources. ICLARM, Manila. p. $1-124$

Ekmekçi FG. 1996. A preliminary study on the growth of mirror carp (Cyprinus carpio L.) introduced to Gelingüllü Reservoir of a newly built dam in (Yozgat) Turkey. Hacettepe Bulletin of Natural Sciences and Engineering 25:1-13.

Fernández-Delgado C. 1990. Life history patterns of the common carp, Cyprinus carpio, in the estuary of the Guadalquivir River in south-west Spain. Hydrobiologia206(1):19-28. doi:10.1007/BF00018966

Freyhof J, Kottelat M 2008. Cyprinus carpio. The IUCN Red List of Threatened Species 2008: e.T6181A12559362. doi:10.2305/

IUCN.UK.2008.RLTS.T6181A12559362.en

Froese R, Pauly D (editors) 2019. FishBase. World Wide Web electronic publication. [accessed 01/12/2019]. Availablefrom http://www.fishbase.org.

Gaygusuz Ö, Gürsoy Ç, Özuluğ M, Tarkan AS, Acıpınar H, Bilge G, Filiz H. 2006. Conversions of total, fork and standard length measurements based on 42 marine and freshwater fish species (from Turkish Waters). Turk J Fish Aquat Sc. 6(2): 79-84.

Kamboj N, Kamboj V. 2019. Morphometric and meristic study of four freshwater fish species of river Ganga. Indian J Anim Sci. 89(4):120-123.

Kırankaya ŞG, Ekmekçi FG, Yalçın-Özdilek Ş, Yoğurtçuoğlu B, Gençoğlu L. 2014. Condition, length-weight and length-length relationships for five fish species from Hirfanl1
Reservoir, Turkey. Journal of FisheriesSciences.com 8(3):208-213. doi:10.3153/jfscom.201426

Mimeche F, Belhamra M, Mimeche Y. 2015. Growth parameters of Cyprinus carpio Linnaeus, 1758 (Cyprinidae) in the K'sob Reservoir in M'sila (Algeria). Courrier du Savoir 19:59-64.

Moradinasab Gh, Daliri M, Ghorbani R, Paighambari SY, Davoodi R. 2012. Length-weight and length-length relationships, relative condition factor and Fulton's condition factor of five cyprinid species in Anzali wetland, southwest of the Caspian Sea. Caspian Journal of Environmental Sciences 10(1):25-31.

Önsoy B, Filiz H, Tarkan AS, Bilge G, Tarkan AN. 2011. Occurrence of non-native fishes in a small man-made lake (Lake Ula, Muğla): past, present, future perspectives. Turk J Fish Aquat Sc. 11(2):209-215. doi:10.4194/trjfas.2011.0205.

Ricker WE, Foerster RE. 1948. Computation of fish production. Bulletin of Bingham Oceanographic College, Yale University 11:173-211.

Ricker WE (Ed.) 1968. Methods for assessment of fish production in fresh waters. Oxford and Edingburgh: Blackwell Scientific Publ. 1968, 313 p. doi:10.1002/iroh.19690540313

Saç G, Okgerman, H. 2016. Büyükçekmece Rezervuarı (İstanbul, Türkiye)'ndaki bazı balık türlerinin boyağırlık ve boy-boy ilişkileri ile kondisyon faktörleri. LimnoFish.2(1):43-48. doi:10.17216/limnofish.205786

Sungur Birecikligil S, Çiçek E, Öztürk S, Seçer B, Celepoğlu Y. 2016. Length-length, length-weight relationship and condition factor of fishes in Nevşehir Province, Kizılırmak River Basin (Turkey). Acta Biologica Turcica 29(3):72-77.

Treer T, Aničić I, Safner R. 1995. The growth and condition of common carp (Cyprinus carpio) introduced to Croatian Vransko Lake. Ribartsvo 53:62-73.

Vilizzi L. 1997. Age, growth and early life history of carp (Cyprinus carpio L.) in the River Murray, South Australia. [PhD Thesis], University of Adelaide, Adelaide, Australia, 239 p. doi: 10.13140/RG.2.2.11811.27681

Vilizzi L. 2012. The common carp, Cyprinus carpio, in the Mediterranean Region: Origin, distribution, economic benefits, impacts and management. Fisheries Manag Ecol.19(2):93-110. doi:10.1111/j.1365-2400.2011.00823.x

Vilizzi L, Copp GH. 2017. Global patterns and clines in the growth of common carp Cyprinus carpio. J Fish Biol.91(1):3-40. doi:10.1111/jfb.13346

Vilizzi L, Tarkan AS, Copp GH. 2015a. Experimental evidence from causal criteria analysis for the effects of common carp Cyprinus carpio on freshwater ecosystems: a global perspective. Rev Fish Sci Aquac. 23(3) :253-290. doi:10.1080/23308249.2015.1051214 
Vilizzi L, Ekmekçi FG, Tarkan AS, Jackson ZJ. 2015 b. Growth of common carp Cyprinus carpio in Anatolia (Turkey), with a comparison to native and invasive areas worldwide. Ecol Freshw Fish. 24(2):165-180. doi:10.1111/eff.12141

Yılmaz S, Polat N, Yazıcıoğlu O. 2010a. Samsun ili içsularında yaşayan sazan (Cyprinus carpio L., 1758)'ın boy-ağırlı ve boy-boy ilişkileri (Length-weight and length-length relationships of common carp (Cyprinus carpio L., 1758) inhabiting inland waters of Samsun Province). The Black Sea Journal of Sciences 1(1): 39-47.
Yılmaz S, Yazıcıoğlu O, Yılmaz M, Polat N. 2010 b. Hirfanlı Baraj Gölü'nde yaşayan Cyprinus carpio L., 1758 ve Tinca tinca (L., 1758)'nın boy-ağırlık ve boy-boy ilişkileri ile mevsimsel kondisyon faktörleri. Süleyman Demirel University Journal of Science 5(2):154-162.

Xie C, Hu Z, Cai R, Pu D, Feng X, Zuogang $\mathrm{P}$, Zhijian W. 2019. Assessment of the growth of eight dominant fish species and their resource development in important tributaries of the Three Gorges Reservoir area. Shuichan Xuebao. 26(3):504-511.

doi:10.3724/SP.J.1118.2019.18391 